\title{
Prevalence of bacterial vaginosis among reproductive age group women in a tertiary care centre
}

\author{
Rema V. Nair*, Raja Preethi, M. Vijayalekshmi
} Department of Obstetrics and Gynecology, Sree Mookambika Institute of Medical Sciences, Kulasekharam,
Kanyakumari, India

Received: 04 July 2019

Accepted: 07 September 2019

*Correspondence:

Dr. Rema V. Nair,

E-mail: vishnusastha@gmail.com

Copyright: (c) the author(s), publisher and licensee Medip Academy. This is an open-access article distributed under the terms of the Creative Commons Attribution Non-Commercial License, which permits unrestricted non-commercial use, distribution, and reproduction in any medium, provided the original work is properly cited.

\begin{abstract}
Background: Vaginal discharge in reproductive age poses a serious problem in the developing countries. Bacterial vaginosis also known as non-specific vaginitis is the most common cause of vaginal infections, detecting the organism at an early stage and initiating a proper treatment is very difficult in our country due to lack of awareness and proper follow-up. The disease manifests in the form of vaginal discharge with or without itching. It has a strong association with preterm labor, preterm premature rupture of membranes and low birth weight in pregnancy. The objective of this study was to find out the prevalence of bacterial vaginosis among the reproductive age group women, in a tertiary care centre.

Methods: A cross sectional study was conducted among 150 women of the reproductive age group in the department of obstetrics and gynaecology Sree Mookambika Institute of Medical Sciences over a period of one month October 2018 the diagnosis was made with history and nugents scoring system.

Results: Out of the total 150 women enrolled in the study 74 had positive results, $50 \%$ of them were of the age group 26-30.

Conclusions: The study shows us the high prevalence of bacterial vaginosis.
\end{abstract}

Keywords: Bacterial vaginosis, Discharge, Preterm, Reproductive age, Vaginal candidiasis, Vaginal floura

\section{INTRODUCTION}

Vaginal discharge in reproductive age poses a serious problem in the developing countries. Detecting the organism at an early stage and initiating a proper treatment is very difficult in our country due to lack of awareness and proper follow-up. ${ }^{1}$ The skin of a normal vagina is lined with tough stratified squamous epithelium devoid of any glands. The high acidity creates a hostile environment for the growth of many pathogens. Besides, the normal flora present in the upper third of the cervical canal viz. Lactobacilli (Doderlein's bacilli), Group B and D streptococci, Coagulase negative Staphylococci, Diptheroids etc., inhibit the growth of harmful flora. ${ }^{2}$ The extremes of age are more prone for vaginal infections.
There are times when the vaginal defence mechanisms are reduced like, during menstruation, after abortion and labor. Some of the specific vaginal infections that occur in the women of reproductive age group are, Bacterial Vaginosis, Moniliasis, Chlamydial, Gonococcal and Trichomonad. Except bacterial vaginosis, the rest of them are mostly sexually transmitted. ${ }^{3}$ Bacterial vaginosis also known as non-specific vaginitis is the most common cause of vaginal infections. The causative organism being Gardnerella vaginalis, the disease in associated with minimal inflammatory response. It is characterized by a change in the vaginal flora with a reduction in the number of Doderlein's bacilli and an increase in Gardnerella vaginalis and resident anaerobic bacilli. The disease manifests in the form of vaginal discharge with or 
without itching. It has a strong association with preterm labor, preterm premature rupture of membranes and low birth weight in pregnancy. It may lead to pelvic inflammatory disease and infertility predisposing factors for Candida infection is mainly due to antimicrobial usage, chemotherapy. ${ }^{4,5}$

Mostly infertility is due to post inflammatory changes in fallopian tube, tube ovarian mass that leads to change in vaginal flora. The other organisms such as mycoplasma, Chlamydia, neiss can also cause infertility. ${ }^{6}$ Most prevalent among the population of low socio economic status and where due to lack of knowledge, vaginal discharge, some of the factors leads to imbalance of the micro organism population-mainly due to immunodeficiency status, sexual activities, antibiotics. These vaginal infections lead to painful sexual intercourse, chronic pelvic pain, itching in the genitals. Changes in secretions like colour, smell, quantity, lesions in vagina will show the symptoms of infection. This study was conducted to study the prevalence of bacterial vaginosis among the reproductive age group women, in tertiary care center, Kulasekharam.

The objective of this study was to find out the prevalence of bacterial vaginosis in reproductive age group.

\section{METHODS}

A cross sectional study was conducted among 150 reproductive age group Women with vaginal discharge attending the Gynaecology outpatient Department at Sree Mookambika Institute of Medical Sciences, Kulasekharam, Kanyakumari district over a period of one month October 2018 were included in the study to determine the incidence of bacterial vaginosis. A detailed history and information regarding age, symptoms, character and quantity of discharge, colour, odour and pruritus were all collected in the questioner. A thorough clinical examination to examine the condition of vagina and cervix was done. An informed consent was taken from all the patients. We collected basic patient like name, age, parity, marital history, potential risk factors were all collected in the questionnaire.

\section{Inclusion criteria}

- Women of reproductive age group with complaints of vaginal discharge in reproductive age group attending the Gynecological OPD of Sree Mookambika Institute of Medical Sciences.

\section{Exclusion criteria}

- Women with chronic autoimmune or inflammatory condition like pelvic inflammatory disease or on any antimicrobials within the previous four weeks, women using any intrauterine device or hormonal contraceptives, burning and dysuria were excluded from the study.
The under strict aseptic condition, high vaginal swabs (HVS) were collected by using Cusco's speculum inserted into the vagina to retract the vaginal walls. Using a sterile long rigid cotton swab was inserted carefully into the uterine cervix rotated gently and sent for culture and sensitivity. A total of 150 women were examined, who were all married, sexually active, between the age group 21 to 45 years were included in the study. Following a complete general examination, per abdomen examination and pelvic examination was performed. For the diagnosis, the Nugent's scoring of gram staining was used.

\section{RESULTS}

Table 1: Characteristics of women.

\begin{tabular}{|lll|}
\hline Age & Number of patients & Percentage \\
\hline $21-25$ & 12 & 16.21 \\
\hline $26-30$ & 37 & 50.00 \\
\hline $31-35$ & 12 & 16.21 \\
\hline$>35$ & 13 & 17.58 \\
\hline
\end{tabular}

Out of the 150 reproductive age group women, $74 \%$ of the study population belongs to upper lower class according to modified Kuppuswamy socioeconomic status. Majority of the study population belongs to 26-30 years.

Table 2: Nugents scoring of gram staining diagnosis of bacterial vaginosis.

\begin{tabular}{|lll|}
\hline Nugents scoring & Positive patients & Percentage \\
\hline $\mathrm{Bv}$ & 33 & 44.8 \\
\hline Intermediate & 11 & 13.6 \\
\hline Normal & 30 & 41.6 \\
\hline
\end{tabular}

0-3: Normal, 4-6: Intermediate, 7-10: BV.

Table 3: Association between BV and other sexually transmitted infections.

\begin{tabular}{|lll|}
\hline Infection & Positive patients & Percentage \\
\hline Candida & 26 & 35.13 \\
\hline Trichomonas & 4 & 5.40 \\
\hline Hiv & 2 & 2.70 \\
\hline Syphilis & 1 & 1.35 \\
\hline
\end{tabular}

$50 \%$ of the women were between the age group 26$30 y e a r s$ of age vaginal discharge collected was smeared on glass slides, dried, heat fixed followed by staining with Gram's staining (Table 1). The bacterial morph type was studied using the following scheme: $1+, 30$ per field. Large gram-positive rods were lactobacillus morphotypes; small gram negative to Gram-variable rods were considered as $G$. vaginalis and Bacteroides spp. morphotypes; curved gram variable rods were considered as Mobiluncus spp. morphotypes. Bacterial vaginosis in this study was $44.8 \%$, intermediate scoring was $13.6 \%$, normal nugent scoring about $41.6 \%$ (Table 2 ). 
Candida infection accounts for $35.13 \%$, trichomonas accounts for $5.40 \%$, HIV association about $2.70 \%$ and syphyllis accounts for $1.35 \%$ (Table 3 ).

\section{DISCUSSION}

There have been multiple studies performed in various parts of India on the prevalence of bacterial vaginosis. The prevalence of bacterial vaginosis in our study was $49.33 \%$ which was higher than the study conducted previously by Sangeeta et al $(40.66 \%)$ and in bardados $(33 \%)^{7,8}$ Various other review literature have been reported between prevalence of $25.4 \%$ to $38.6 \%{ }^{9}$ Vaginal candidiasis in our study was $35.13 \%$ and higher than trichomoniasis like the same found in Watch arotoneet al, there is also relation between contraceptive usage and many people in the study were unaware of the condition and serious complications associated with it like HIV, HPV etc, and many people were shy to cooperate fully in the study which is also true in many other study. ${ }^{10-12}$ The highest frequency of (66.21\%) vaginal candidiasis was observed in the age group of second decade (20-30) years, followed by age group of (30-40) years. Females above 40 years showed lower incidence as observed in our study which is in concordance with previous studies reported by Ako et al. ${ }^{13}$ A research study undertaken by Sehgal also showed the age group 21-30 years had the highest incidence of vaginal candidiasis coinciding with our observation indicating women of childbearing age groups are more vulnerable to vaginal candidiasis.

\section{CONCLUSION}

The study shows us the high prevalence of Bacterial Vaginosis, need of routine pap smear, needs to be emphasized to the women in the reproductive age group. The easy mode of diagnosis and treatment needs to be stressed on to prevent morbidities, health education regarding the complications related to bacterial vaginosis should be explained to the population.

\section{Funding: No funding sources}

Conflict of interest: None declared

Ethical approval: The study was approved by the Institutional Ethics Committee

\section{REFERENCES}

1. Bhalla P, Chawla R, Garg S, Singh MM, Raina U, Bhalla $\mathrm{R}$, et al. Prevalence of bacterial vaginosis among women in Delhi, India. Indian $\mathrm{J}$ Med Res. 2007; 125:167-72.

2. Sood N, Sud SS. Profile of infection in women with vaginal discharge in North India. Int $J$ Reprod Contracept Obstet Gynecol. 2018;7:4184-9.

3. Babu G, Singaravelu BG, Srikumar R, Reddy SV. Comparative study on the vaginal flora and incidence of asymptomatic vaginosis among healthy women and in women with infertility problems of reproductive age. J Clin Diag Res. 2017;11(8):DC18.

4. Eschenbach DA, Hillier S, Critchlow C, Stevens C, De Rousen T, Holmes KK. Diagnosis and clinical manifestations of BV. Am J Obstet Gynaecol. 1988;158:819-28.

5. Samal R, Vaithy A, Kotasthane DS, Ghose S. Prevalence and clinico-mycological profile of vulvovaginal candidiasis in a tertiary care hospital. Int $\mathbf{J}$ Reprod Contracept Obstet Gynecol. 2015;4:1142-7e.

6. Jogi SR, Babbar K. Prevalence of bacterial vaginosisin sexually active females in Chhattisgarh Institute of Medical Sciences, Bilaspur, Chhattisgarh. Int J Reprod Contracept Obstet Gynecol. 2015;4:963-7.

7. Levett PN, Taruvinga M, Maheswaran K, RotchellY. Genital tract infections in sexually active womenin Barbados. West Indian Med J. 1995;44:128-9.

8. Bhalla P, Chawla R, Garg S, Singh MM, Raina UBhalla R. Prevalence of bacterial vaginosisamong women in Delhi, India. Indian $\mathbf{J}$ Med Res. 2007; 125:167-72.

9. Watcharotone W, Sirimai K, Kiriwat O, Nukoolkarn $\mathrm{P}$, Watcharaprapapong $\mathrm{O}$, Pibulmanee $\mathrm{S}$, et al. Prevalence of bacterial vaginosis in Thai women attending the family planning clinic, Siriraj Hospital. J Med Assoc Thai. 2004;87:1419-24.

10. Amsel R, Totten PA, Spiegel CA, Chen KC, Eschenbach D, Holmes KK. Non-specific vaginitis. Diagnostic criteria and microbial and epidemiologic, associations. Am J Med. 1983;74(1):14-22.

11. Seth AR, Chaitra S, Vaishnavi S, Chandra GR. Prevalence of bacterial vaginosis in females in the reproductive age group in Kadur, Karnataka, India. Int J Repro Contra Obstet Gynecol. 2017;6(11):4863-5.

12. Ako-Nai A, Kassim O, Adeniran M. Study of urinary tract infections at Ile-Ife, Nigeria. East African Med J. 1993;70:10-4.

Cite this article as: Nair RV, Preethi R,

Vijayalekshmi M. Prevalence of bacterial vaginosis among reproductive age group women in a tertiary care centre. Int J Reprod Contracept Obstet Gynecol 2019;8:4515-7. 